\title{
Durus Al-Lughah Gontory: Interactive Arabic Mobile Learning for Beginners
}

\author{
Dihin Muriyatmoko ${ }^{1}$, Achmad Farouq Abdullah ${ }^{2}$, Zaenury Adhiim Musyafa, ${ }^{3}$
}

\begin{abstract}
The goal of the Android mobile application for Arabic learning is to help students who are not alumni of Muslim boarding school in everyday interaction using the Arabic language at Universitas Darussalam Gontor and to function as a medium to introduce Arabic of Pondok Modern Darussalam Gontor version to beginners. The contents come from the book of the first edition of chapter 1 to 12 written by KH. Imam Zarkasyi and KH. Imam Syubani. These books are studied by santri of KMI PMDG of class one. This application applies grammar translation and audiolingual method to learn Arabic for beginners and is developed using ADDIE (analysis, design, development, implementation, and evaluation) approach model. The test was done in six ways: its compatibility with any android device at least 4.5 inchi with the type of android mimimum version of 4.0.4 (Ice Cream Sandwich), an expert material of Arabic language learning give rate score $95 \%$, an expert of media learning give rate score $88.9 \%, 7$ of 11 lecturers of Arabic language give an average score of $81.4 \%, 6$ of 30 students from non-alumni muslim boarding school at this campus give $91.6 \%$ and 373 general users via playstore from February 1, 2017, to November 18, 2017, rated 4.9. The result of the overall evaluation of all the tests on this apps shows that this application is relevant to beginner users because of its ease. However, it cannot replace the role of teacher, class, and situation of real Muslim boarding school.
\end{abstract}

Keywords--durus al-lughah, Gontor, mobile learning, Arabic mobile learning, Arabic learning media.

\section{INTRODUCTION}

Arabic has become the daily language in Islamic boarding schools and the symbol of pride and honor, including at Pondok Modern Darussalam Gontor (PMDG). In historical records, in 1926, when the representatives of Indonesia were invited to attend the Congress of Muslims of the world in Mecca, Indonesia sent two representatives, namely KH. Mas Mansur as Arabic linguists and HOS Tjokroaminoto as an expert in English, because at that time there was as yet no one had mastered both languages well. It was the beginning of the establishment of PMDG, Trimurti, intended to establish an institution with Arabic as the door to master Islamic science and English as a medium to master science, which is then it is

${ }^{1}$ Lecturer, Informatics Engineering of Universitas Darussalam Gontor, Jl. Raya Siman Km.6, Siman Ponorogo 63471 (tlp: 0352483 762; fax:0352-488 182; e-mail: dihin@unida.gontor.ac.id)

${ }^{2}$ Lecturer, Techincal Education of Arabic langage of Darussalam Gontor, Jl. Raya Siman Km.6, Siman Ponorogo 63471 (tlp: 0352483 762; fax: 0352-488 182; e-mail: farouqabdullah373@gmail.com)

${ }^{3}$ Informatics Engineering of Universitas Darussalam Gontor, Jl. Raya Siman Km.6, Siman Ponorogo 63471 (tlp: 0352-483 762; fax: 0352-488 182; e-mail: zaenury.adhiim@unida.gontor.ac.id) termed 'creating intellectual Muslim scholars, not the intellects who know the religion only" [1],

Over time, in 1958 Trimurti gave this institution to the Muslims, stipulated in the endowment certificate, and had began developing the institution from level elementary school (Tarbiyatul Atfal), junior high school/senior high school (Kulliyatul Mualimin Al-Islamiyya/KMI) to university from 1942, establishing the underbow and Bovenbow, then in 1963 became the Institute of Education Darussalam (IPD), then in 1994 became Institute Studi Islam Darussalam Gontor (ISID Gontor), and lastly, in 2014, became Universitas Darussalam Gontor. At this university, all students and lecturers live and interact in the same atmosphere of the Islamic boarding university for 24 hours [2].

Since the shift of this higher institution, from institute to university, it has started attracting a lot of students who come from non-alumni of Islamic boarding school such as senior high school/vocational school. Due to the background of the students on this campus mostly from KMI Gontor and Islamic boarding schools, the Arabic language is often used in everyday life. This is a problem for students of non-alumni of the Islamic boarding school, evidenced by the students taking matriculation of the Arabic language [3].

One way to overcome this problem is education with digital media-based Arabic learning of Android in which the materials are adapted to meet the standard language in the PMDG which the contents are taken from the book Al-lughah durus KH works. Imam Zarkasyi (one of the Trimurtis) and KH. Imam Syubani (a student of the Trimurti). The reason of the use of the mobile app is that all students of matriculation had already used Android smartphones and the process of learning to use traditional media (book) might not be done in certain circumstances, for example, is on the way. In addition, the mobile app is expected to increase the benefits of smartphones.

This paper discusses the design technique of Arabic learning media that applies grammatical translation and audiolingual method which its construction uses a model of Analysis, Design, Development, Implementation, and Evaluation (ADDIE). The development of this learning media also involves several parties, namely experts in the Arabic language materials at PMDG, instructional media experts at PMDG, seven lecturers of Arabic language at Universitas Darussalam Gontor and teachers of KMI PMDG who are experts in the Arabic language at Universitas Darussalam Gontor. This learning media is not only devoted to students who are not alumni of the Gontor, but it can also be used for the general users who want to know the Arabic language version of PMDG because it is Arabic for beginners. Here is the plan for the development of Android mobile Arabic learning media. 
TABLE I

DEVELOPMENT Plan For INTEGRATION OF DURUS AL-LughaH BOOK INTO MOBILE APP BASED ON ANDROID MOBILE

\begin{tabular}{|l|l|l|l|}
\hline \multirow{2}{*}{ Durus book Al-lughah } & \multicolumn{3}{|c|}{ Status } \\
\cline { 2 - 4 } & Beginner & Medium & Advanced \\
\hline Volume 1 chapters 1-12 & Published & & \\
\hline Volume 1 chapters 13-24 & & Process & \\
\hline Volume 2 chapters 1-12 & & Process & \\
\hline Volume 2 chapters 13-24 & & & Process \\
\hline
\end{tabular}

The main content of research done in this paper is the book Al-lughah durus volume 1 from chapter 1 to chapter 12 , according to Table I, which is intended for the beginners taught to students of KMI PMDG class 1 or equivalent.

This study is the result of collaboration between Informatics and Arabic Education program which is a continuation of the development of previous research seminar. However, this study is still at the design stage and then in this paper, it is continued to development stage to its implementation and evaluation [4]. There is a change in the title of Tamrin Lughoh learning media into Durus Al-lughah because at the time of implementation there is a revision from the heirs and Arabic language experts at Universitas Darussalam Gontor.

\section{ARABIC LANGUAGE LEARNING MEDIA}

Research on Arabic learning media is not much. A study of designing Android-based learning media for Arabic vocabulary provides assessment results that the application is feasible to use to help students memorize vocabulary in Arabic, but the media is still limited to memorizing vocabulary [5]. Research on Android-based application hadith provides feedback results that the application is attractive, easy to understand, the material is also appropriate, but the media is also still on the content of the hadith [6]. Research on Arabic grammar/sharf provides results that in studying Arabic grammar, students should not rely on formal learning places, but it can be done from Android smartphone owned. However, this media is still limited to learn the rules of Arabic grammar [7]. Research on the use of digital books in learning Arabic using Android provides results of increased motivation and skills in learning to read in Arabic. This media is also still limited to improving literacy [8]. Research applications of Android-based Arabic vocabulary provide increased proficiency in Arabic vocabulary in a relevant and consistent way, but the media was limited to learning advanced vocabulary [9]. From learning Arabic using Information and Communication Technology, it can be concluded that the model can be considered as a medium of learning and teaching materials that can increase student motivation to learn Arabic, because it can be operated alone easily outside class hours and the role of the teacher becomes a motivator and mediator for materials which require a more detailed explanation for the learners in the media that now it has full feature of listening skills of vocabulary, audiolingual, communicating, reading, exercises, and writing. However, the adapted materials are not from a special primary source book characterizing an Islamic boarding school and also in the learning process, it still requires a personal computer (PC) or laptop because the medium is still in the form of DVDs/CDs [10].

Of the six studies that have been mentioned, each has disadvantages and advantages. The most significant weakness is the source of material used is not derived from the Arabic language textbook used for students at an Islamic boarding school or pesantren that has been shown to produce graduates who are able to master the Arabic language well as in the PMDG. This mobile application will also serve as the hallmark of PMDG of Universitas Gontor Darussalam who wish to have a mobile-based learning media [11].

This learning media is created with the software of Android Studio version 2.2.3 made by Google Inc. which can be downloaded for free on the web https://developer.android.com/studio/index.html and the data storage uses SQLite that are already contained in Android Studio itself. The process of developing, revision, implementation, testing, and evaluation of instructional media take approximately sixteen months, from August 2016 to November 2017

\section{APPLICATION DESIGN}

In the design of this Android-based learning media, it is used a mixture of application of two methods of grammartranslation and audiolingual, as well as in developing it uses ADDIE model.

\section{A. Grammar Translation}

This method is actually a mixture of two methods: Grammar (English) or Grammatika (Arabic) or Tata Bahasa (Indonesian) and Translations (English) or Tarjamah (Arabic) or terjemahan (Indonesian) are often regarded as a unity method, which is the traditional method of learning a foreign language, in this case Arabic explaining how to study language grammar analysis sharpens language structures on a word or phrase that is done in a way to read and translated in Arabic [12]. This method aims to make students smart in understanding and memorizing grammar texts, especially the language used in everyday life. The characteristic of this method is that the language of instruction could be in the form of a bilingual dictionary memorized, the original word and translation, examples of sentences and conversation texts in the original language, in this case, it is the Arabic language [13]. The use of this method is very practical and closely related to the Arabic grammatical rules (nahwu) and morphology (sharaf). However, the most important point of the application of the method is not just memorization, but also must have the courage to speak directly with people who are of course also Arabic language experts [14].

\section{B. Audiolingual}

This method is an exercise of foreign language (Arabic) by listening and reciting the word or phrase heard, or in short, listening and pronouncing [15]. The purpose of this method is the understanding of the word or phrase that is heard and is able to recite the word or phrase that has been heard and understood, can be by sentence or word that is the same or 
different, but without changing its meaning [16]. Characteristics of the audiolingual method are listening practice, comprehension, and reciting continually, either using unassisted or with the help of other media, such as objects, images, animation, and video [17].

\section{Analysis, Design, Development, Implementation, Evaluation (ADDIE) model}

This method is most often found in scientific articles related to multimedia learning. The application of this learning media is described as follows [18].

1) Analysis: At this stage, observation and collection of data to detect problems are conducted, especially when the new students enroll at Universitas Darussalam Gontor as shown in Table II.

TABLE II

IMPLEMENTATION OF PHASE ANALYSIS ON LEARNING MEDIA

\begin{tabular}{|c|l|l|}
\hline No. & \multicolumn{1}{|c|}{ Event } & \multicolumn{1}{c|}{ Results } \\
\hline 1 & $\begin{array}{l}\text { Identifying the } \\
\text { problem during a test } \\
\text { of new students. }\end{array}$ & $\begin{array}{l}\text { In written and interview test, it } \\
\text { is found prospective students } \\
\text { who are not alumni of Islamic } \\
\text { boarding school or vocational } \\
\text { school / high school who do not } \\
\text { pass the tests and must attend } \\
\text { the Arabic language } \\
\text { matriculation for one year. }\end{array}$ \\
\hline 2 & $\begin{array}{l}\text { Standard assessment } \\
\text { considerations of } \\
\text { Arabic spoken used. }\end{array}$ & $\begin{array}{l}\text { The standard of Arabic language } \\
\text { at Universitas Darussalam } \\
\text { Gontor University is in } \\
\text { accordance with the PMDG. }\end{array}$ \\
\hline 3 & $\begin{array}{l}\text { Study of the } \\
\text { content/contents of } \\
\text { references in the } \\
\text { Arabic language used. }\end{array}$ & $\begin{array}{l}\text { Reference to the Arabic } \\
\text { language used for PMDG is } \\
\text { Durus Al-lughah Book Volume } \\
1 \text { chapters 1-12 KH Imam } \\
\text { Zarkasyi and KH. Imam } \\
\text { Syubani. }\end{array}$ \\
\hline 4 & Solutions offered. & $\begin{array}{l}\text { Developing Arabic Learning } \\
\text { media that can be used } \\
\text { independently. }\end{array}$ \\
\hline 5 & $\begin{array}{l}\text { The technology used } \\
\text { for solutions. }\end{array}$ & $\begin{array}{l}\text { Developing media of Android- } \\
\text { based Arabic learning. }\end{array}$ \\
\hline 6 & $\begin{array}{l}\text { Technological } \\
\text { Considerations. }\end{array}$ & $\begin{array}{l}\text { Users or prospective students } \\
\text { have Android-based } \\
\text { smartphones. }\end{array}$ \\
\hline
\end{tabular}

According to Table II at number 3, after discussions with linguists and several lecturers of Arabic Education program at Universitas Darussalam Gontor, the study of the content was taken from the book Al-lughah Durus KH Imam Zarkasyi and KH. Imam Syubani the first volume from chapter 1 to chapter 12 , which would be incorporated into this instructional media consisting of such things as presented in Table III.

2) Design: At this stage, it was made a further step after a solution found in Table II of flowcharts how learning media works as presented in Fig. 1.

In addition, this phase describes activities and the achievement of learning media as shown in Table IV.
TABLE III

DATA MEDia CONTENT LEARNING

\begin{tabular}{|c|c|}
\hline Material & Specification \\
\hline 1 & Use of nouns and signal words/Mudzakkar (male). \\
\hline 2 & $\begin{array}{l}\text { The use of nouns and signal words/Mudzakkar } \\
\text { (male) and mu'annas (female). }\end{array}$ \\
\hline 3 & $\begin{array}{l}\text { Differences in the use of nouns and signal } \\
\text { words/Mudzakkar (male) and mu'annas (female). }\end{array}$ \\
\hline 4 & Use and mentioning nouns with "here" and "there". \\
\hline 5 & $\begin{array}{l}\text { Use and stating the position of objects with the letter } \\
\text { jar and zharf (above, in, under, between, behind, in } \\
\text { front, above (not attached)). }\end{array}$ \\
\hline 6 & $\begin{array}{l}\text { Use of nouns dhamir/indicating ownership (his, her, } \\
\text { my, he, and she) several basic nouns. }\end{array}$ \\
\hline 7 & $\begin{array}{l}\text { Use of nouns dhamir/indicating ownership (his, her, } \\
\text { my, he, and she) several advanced nouns. }\end{array}$ \\
\hline 8 & $\begin{array}{l}\text { The use of numbers (mufrad and jama') for } \\
\text { Mudzakkar (male) in a sentence. }\end{array}$ \\
\hline 9 & $\begin{array}{l}\text { Differences in the use of numbers (mufrad and jama') } \\
\text { for Mudzakkar (male) and mu'annas (female) in a } \\
\text { sentence (noun base). }\end{array}$ \\
\hline 10 & $\begin{array}{l}\text { Differences in the use of numbers (mufrad and jama') } \\
\text { for Mudzakkar (male) and mu'annas (female) in a } \\
\text { sentence (advanced nouns). }\end{array}$ \\
\hline 11 & $\begin{array}{l}\text { The use of the word laisal instead of (I, we, you for } \\
\text { women, you for men, she, and he). }\end{array}$ \\
\hline 12 & $\begin{array}{l}\text { The use of computation of males }(11-20) \text { in a } \\
\text { sentence. }\end{array}$ \\
\hline
\end{tabular}

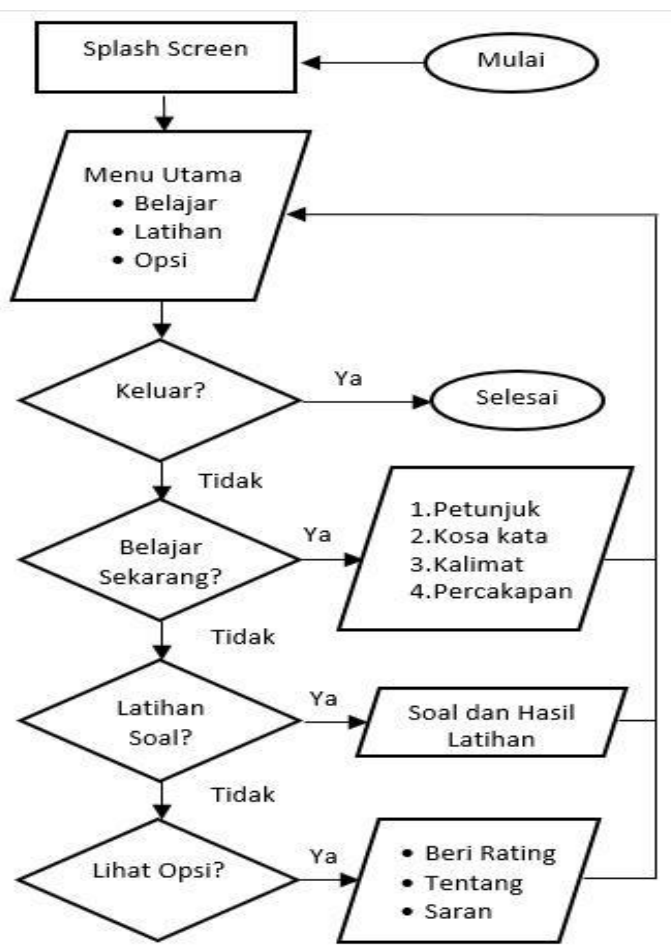

Fig. 1 Flowchart of use of instructional media.

In Fig. 1, users open their instructional media learning media after downloading from Google Android Play Store, either through the menu Play Store on Android smartphones 
by typing the keyword "Al-lughah durus" or can directly open the link or address https://play.google.com /store/apps/details?id=com.unida.zheezhee.tamrinlughohgonto ry\&hl=en). Then, users can directly install this learning media on smartphones for free with no ads. The first menu that appears is the splash screen, then enter the main menu that contains lessons 1 to 12 , exercises and menu options, the menu contains instructions for each lesson lessons, vocabulary along with sound, example sentences, conversations, and also navigation exercises. Furthermore, the options menu consists of three main points, namely button to give a rating to this media directly to Google Play Store, about the program developer, and suggestions by sending an email the developer.

TABLE IV

ACTIVITY AND EXPECTED RESULTS

\begin{tabular}{|c|l|l|}
\hline No. & \multicolumn{1}{|c|}{ Activity } & \multicolumn{1}{c|}{ Expected Results } \\
\hline 1 & $\begin{array}{l}\text { Reading } \\
\text { lesson }\end{array}$ & $\begin{array}{l}\text { Able to understand the instructions for each } \\
\text { lesson, the meaning of the vocabulary, } \\
\text { examples of sentences and conversations. }\end{array}$ \\
\hline 2 & Listening & $\begin{array}{l}\text { Able to hear and recite again each menu of } \\
\text { vocabulary in each lesson. }\end{array}$ \\
\hline 3 & Speaking & $\begin{array}{l}\text { Capable of acting as a questioner and } \\
\text { answering questions on the conversation } \\
\text { menu of each lesson. }\end{array}$ \\
\hline 4 & $\begin{array}{l}\text { Answering } \\
\text { questions }\end{array}$ & $\begin{array}{l}\text { Able to answer all questions from the } \\
\text { summary of chapter 1 to chapter 12. }\end{array}$ \\
\hline
\end{tabular}

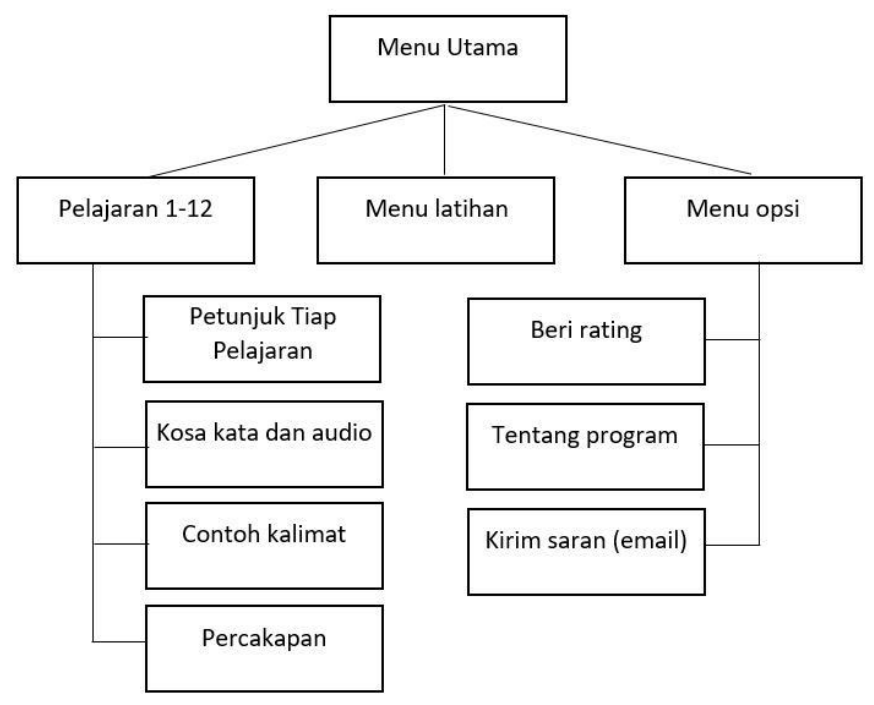

Fig. 2 Hierarchical models of learning media.

3) Development: Next, the hierarchical model according to Fig. 2 consists of three selection menus, the menu consists of guidance, vocabulary, examples of sentences, and conversations; menus of exercises that contains questions from the lesson of 1 to 12 ; and option menus to provide a rating of the media, knowing media developers, and providing advice to developers of instructional media.

4) Implementation: Implementation is the results of the Android-based learning media "Al-lughah durus Gontory Volume 1".

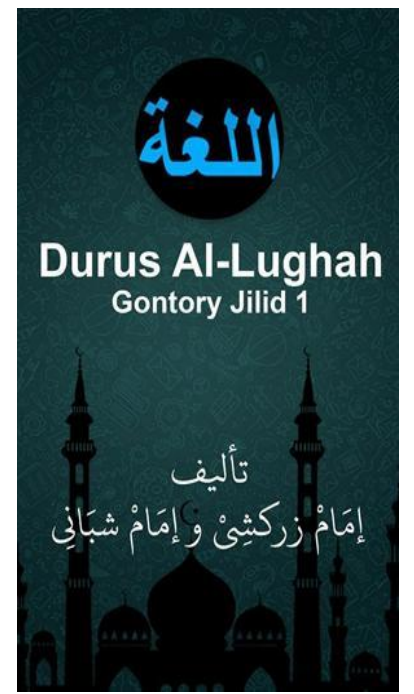

Fig. 3 The splash screen of learning media.

The splash screen in Fig. 3 shows the title of the learning media in Latin writing and Arabic (Al-lughah: language) and with the permission and advice of the heirs of the book of Durus Al-lughah, which earlier in the page of splash screen does not appear the author, then in this continuing research the authors of the book "Ta'lim Imam Zarkasyi and Imam Syubani" are presented.

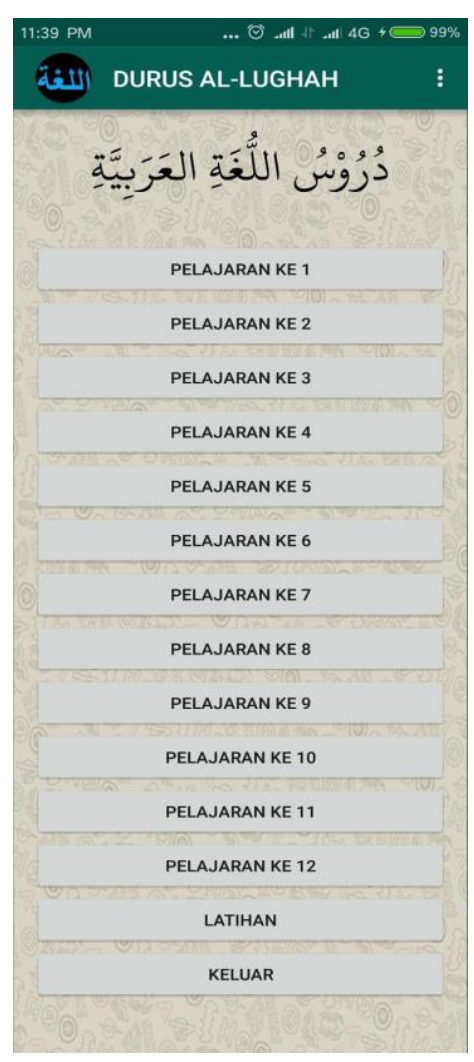

Fig. 4 Main menu.

At the main menu, as shown in Fig. 4, there are buttons of lesson 1 to 12, the button of exercise, and the button to exit the program. Additionally, Fig. 5 presents option menus to 
rate or the updated rating, about the program, and the suggestions of users to the developer via email.

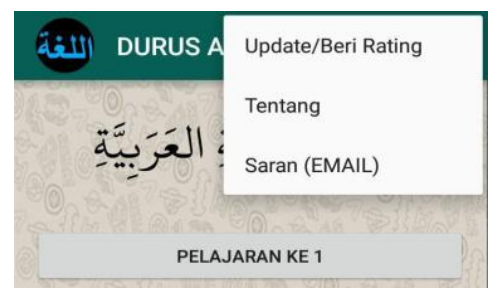

Fig. 5 Option menu.

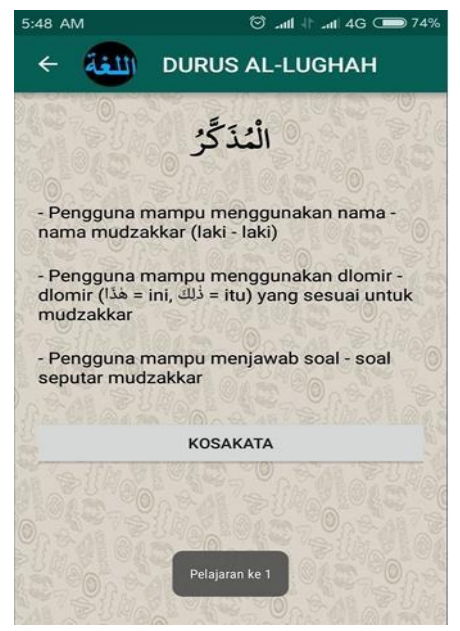

Fig. 6 User menu lesson of learning media.

Fig. 6 is a user menu with an explanation before the user proceeds to the vocabulary menu which is the application of the grammatical method.

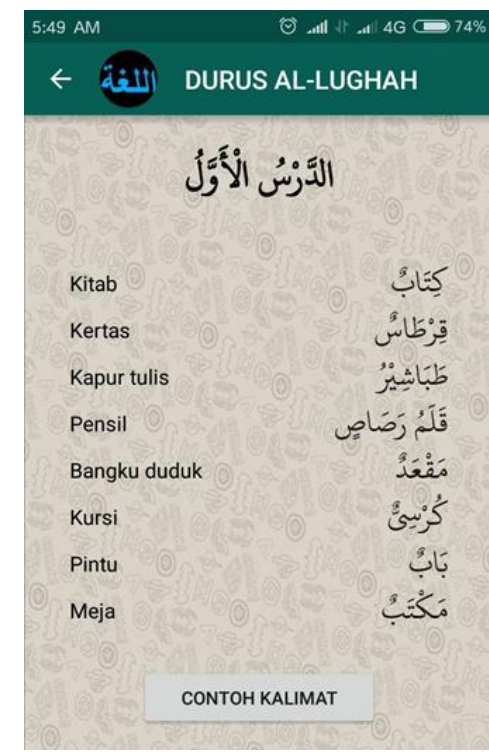

Fig. 7 Menu vocabulary learning media.

The menu in Fig. 7 is a Vocabulary menu, which contains the words in the Arabic language and its translations in the Indonesian and Arabic script when it is pressed, it can be heard the sound as stated, which it is also an application of the method of audiolingual and translation.

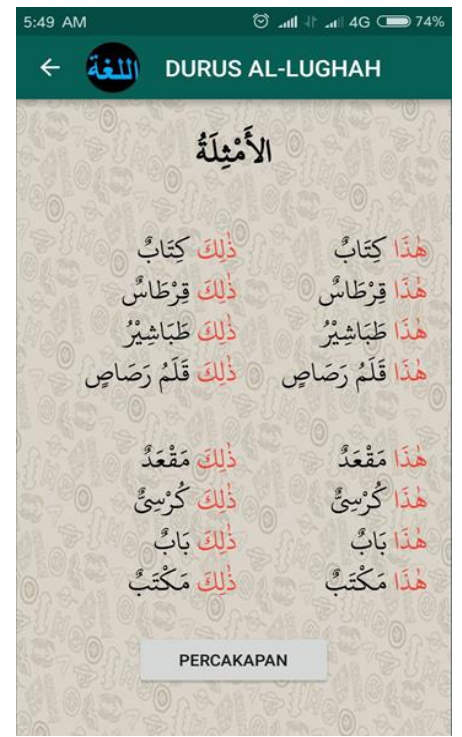

Fig. 8 Menu of examples of sentences of instructional media.

Fig. 8 shows examples of sentences in Arabic. Red writing is a marker that the lesson is more emphasis on grammar. For example, in Fig. 8 the paper emphasizes the meaning of the word "this" and "that" for use in males (Mudzakkar).

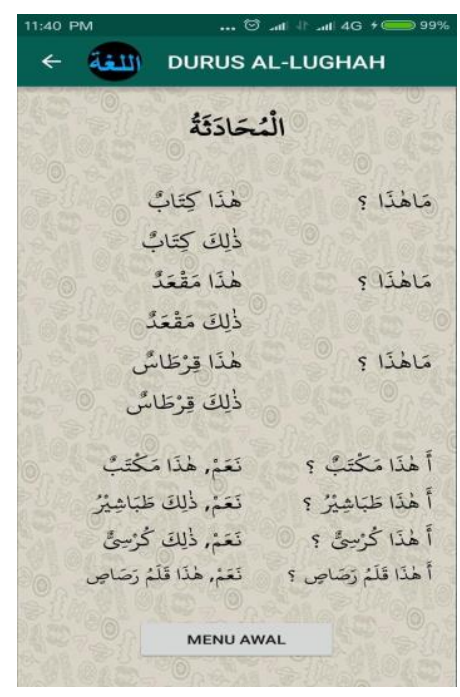

Fig. 9 Menu learning media conversation.

Fig. 9 shows conversations or questions and answers are the examples of sentences to further explore the grammar. In Fig. 8 and Fig. 9, the translations are accidentally dispensed so that users do not look at the translation, but they can develop their own thoughts.

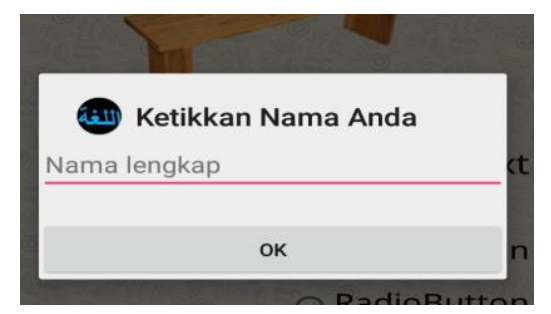

Fig. 10 Completing identity as a medium of learning exercises. 


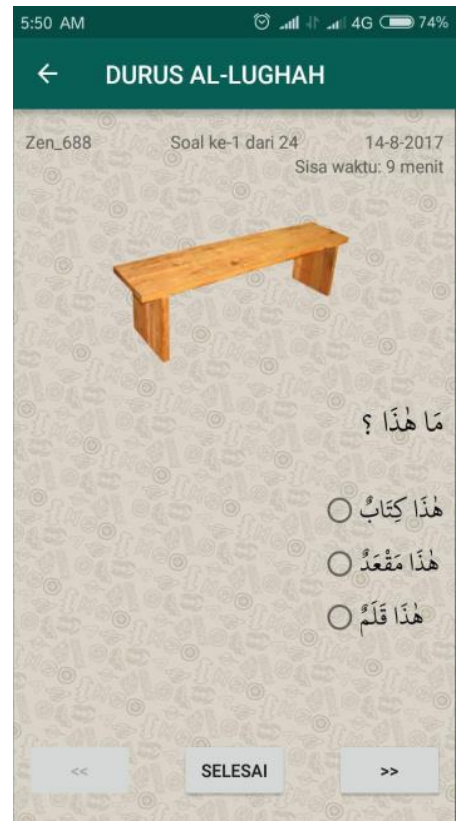

Fig. 11 The menu of exercises of instructional media.

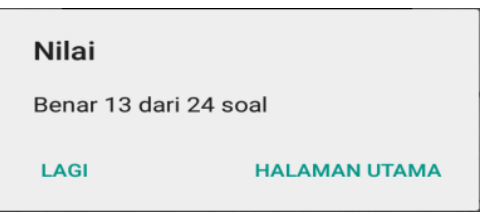

Fig. 12 The results of the exercise of instructional media.

Menus in Fig. 10, Fig. 11, and Fig. 12 are menus of exercises after the button is pressed in the main menu. This menu contains the name to be completed, answering questions, and the results of exercises after finishing work.

5) Evaluation: At the last stage of this evaluation of instructional media software form the error of the program and the content side is done by adjusting to the book of Allughah Durus, both with hardware of real smartphone or emulator from the Android Studio.

\section{Testing AND DisCUSSION}

\section{A. Software Functionality Test}

The test aims to examine the extent to which the device is appropriate, in terms of screen size and brand (type) of the device. This media is set up for an Android device that has an operating system Ice Cream Sandwich (i) due to the current versions are KitKat to Nugget $(\mathrm{k}, \mathrm{l}, \mathrm{m}, \mathrm{n})$. Table $\mathrm{V}$ presents the results of the test that it can then be concluded that the media is suitable for Android devices with a minimum size of the 4.5-inch screen, while the screen below it will have different display, which has a shortage among Arab letter many that do not fit or down the line to under. The processor speed and RAM is not a problem because the media is no process calculations and the size of the file is about $7 \mathrm{Mb}$ so that it provides enough empty space to the internal or external memory of $10 \mathrm{Mb}$.
TABLE V

COMPATIBILITY OF DEVICE OF TYPE AND SCREEN SiZE

\begin{tabular}{|c|c|c|c|}
\hline No. & $\begin{array}{c}\text { Brands and Types of } \\
\text { Devices }\end{array}$ & $\begin{array}{c}\text { Screen Size } \\
\text { (inches) }\end{array}$ & $\begin{array}{c}\text { Compatibility } \\
\text { Results }\end{array}$ \\
\hline 1 & Asus Zenfone 2 Laser & 5 & Yes \\
\hline 2 & Samsung Galaxy J2 & 4.7 & Yes \\
\hline 3 & Xiaomi Redmi Note 4 & 5.5 & Yes \\
\hline 4 & Samsung Galaxy Note5 & 5.7 & Yes \\
\hline 5 & Acer GT- 810 & 8 & Yes \\
\hline 6 & 1609Vivo & 5.5 & Yes \\
\hline 7 & Vivo Y55s & 5.2 & Yes \\
\hline 8 & Smartfren A16C3H & 4.5 & Yes \\
\hline 9 & Andromax i & & 4 \\
\hline 10 & A33w Oppo & 5 & Yes \\
\hline 11 & Oppo A37f & 5.5 & Yes \\
\hline 12 & Oppo A51w & 5 & Yes \\
\hline 13 & Lenovo A7000 & 5.5 & Yes \\
\hline 14 & Lenovo A7700 & 5.5 & Yes \\
\hline 15 & Advan digital 5059 & 5 & Yes \\
\hline 16 & Advan digital S4Z & & 4 \\
\hline 17 & Asus Zenfone Live & 5 & Yes \\
\hline 18 & Asus Zenfone 6 & 6 & Yes \\
\hline 19 & Asus Zenfone Go & 5 & Yes \\
\hline 20 & Sony Xperia Z Ultra & $6: 44$ & Yes \\
\hline 21 & Evercoss S50 & 5 & Yes \\
\hline 22 & Huawei Y520-U22 & 4.5 & Yes \\
\hline 23 & $\begin{array}{l}\text { Asus Fonepad } \\
\text { ME371MG }\end{array}$ & 7 & Yes \\
\hline 24 & MEIZU_M5 & 5.2 & Yes \\
\hline 25 & Lenovo S850 & 5 & Yes \\
\hline 26 & Infinix HOT 4 Pro & 5.5 & Yes \\
\hline 27 & Samsung Galaxy A5 & 5 & Yes \\
\hline 28 & $\begin{array}{l}\text { Samsung Galaxy Tab2 } \\
10.1\end{array}$ & 10.1 & Yes \\
\hline 29 & $\begin{array}{l}\text { Samsung Galaxy Tab2 } \\
7.0\end{array}$ & 7 & Yes \\
\hline 30 & Xiaomi Mi 5 & $5: 15$ & Yes \\
\hline 31 & Samsung Galaxy J1 & 4.3 & No \\
\hline 32 & Samsung Galaxy J1 Ace & 4.3 & No \\
\hline 33 & Samsung Galaxy J7 & 5.5 & Yes \\
\hline 34 & Xiaomiredmi Note 3 & 5.5 & Yes \\
\hline 35 & Xiaomi Redmi 3S & 5 & Yes \\
\hline 36 & Xiaomi Redmi Note 4 & 5.5 & Yes \\
\hline 37 & Samsung Galaxy On5 & 5 & Yes \\
\hline 38 & $\begin{array}{l}\text { Samsung Galaxy J7 } \\
\text { Prime }\end{array}$ & 5.5 & Yes \\
\hline 39 & Xiaomi Redmi 4 & 5 & Yes \\
\hline 40 & Samsung Galaxy S Duos3 & & 4 \\
\hline
\end{tabular}

\section{B. Test of Learning Materials}

This test aims to examine the extent to which learning materials are suitable for beginners. This media is tested to an Arabic language materials in PMDG by Dr. Abdul Hafiz Zaid, who is a graduate of Bachelor level in Al - Azhar University, Cairo Egypt, the degree of Master from Institute of Arab Research and Studies, Cairo Egypt, and the degree of Doctor in the State Islamic University of Maulana Malik Ibrahim Malang, who is also an Arabic teacher at PMDG ( KMI) and lecturer of Arabic of Graduate Program of Universitas Darussalam Gontor who has experienced in teaching Arabic 
for more than 13 years. Questionnaire results are shown in Table VI. The results of the questionnaire show that the maximum value of twelve elements of content is suitable for beginners.

TABLE VI

QUESTIONNAIRE OF LEARNING MATERIALS EXPERT PMDG

\begin{tabular}{|c|l|l|c|}
\hline No. & \multicolumn{1}{|c|}{ Element } & \multicolumn{1}{|c|}{$\begin{array}{c}\text { Value } \\
\text { Letter }\end{array}$} & $\begin{array}{c}\text { Value } \\
\text { Score }\end{array}$ \\
\hline 1 & Clarity of presentation of the material. & Good & 4 \\
\hline 2 & $\begin{array}{l}\text { The material in the media is relevant } \\
\text { to the material to be learned by } \\
\text { students (beginners). }\end{array}$ & Very good & 5 \\
\hline 3 & $\begin{array}{l}\text { The concept of media has correct and } \\
\text { appropriate materials. }\end{array}$ & Very good & 5 \\
\hline 4 & Structure of media is easy for users. & Very good & 5 \\
\hline 5 & $\begin{array}{l}\text { Learning objective of the media is in } \\
\text { accordance with the material. }\end{array}$ & Good & 4 \\
\hline 6 & $\begin{array}{l}\text { Media encourages students to deepen } \\
\text { the content of the material. }\end{array}$ & Very good & 5 \\
\hline 7 & $\begin{array}{l}\text { The presentation is communicative } \\
\text { and interactive }\end{array}$ & Very good & 5 \\
\hline 8 & System / groove / logic is clear. & Good & 4 \\
\hline 9 & $\begin{array}{l}\text { Image illustration on exercises is } \\
\text { relevant to the material. }\end{array}$ & Very good & 5 \\
\hline 10 & The media does not cause ambiguity. & Very good & 5 \\
\hline 11 & Helping effectiveness of learning. & Very good & 5 \\
\hline 12 & Enhancing students' understanding. & Very good & 5 \\
\hline \multicolumn{2}{|l|}{ Average } & Excellent & 9.5 \\
\hline
\end{tabular}

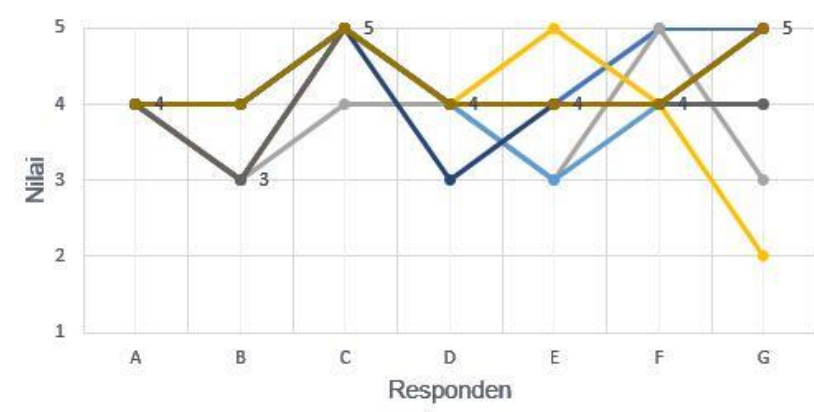

- Kesesuaian materi buku dengan media

$\rightarrow$ Sistematika penyusunan materi

$\rightarrow$ Penyajian

$\rightarrow$ Kejelasan audio

-Kemudahan pemahaman materi

$\rightarrow$ Ketertarikan terhadap media

$\rightarrow$ Kejelasan huruf

$\rightarrow$ Motivasi murid terhadap media

$\rightarrow$ Mengurangi kebosanan

$\rightarrow$ Memudahkan pemahaman materi

Fig. 13 The results of the questionnaire with respondents lecturer Arabic Language Study Program.

In addition, this media is also tested to seven of eleven lecturers of Arabic Education Program which the results are shown in Fig. 13. It appears that this media is suitable for beginners. In addition to the results of the questionnaire in the form of numbers, respondents also commented that one of them is "At Gontor memorize one word that is repeated in many models of the main sentence is more than memorize a lot of words but not used for many models of the sentence". The word is also applied to this medium in Fig. 7 and Fig. 8.

\section{Test of Learning Media}

This test is intended to check the conformity between the media, materials, and users are being targeted. This media is tested by a senior teacher Arabic learning media expert PMDG, Al Ustadz Agus Budiman, M.Pd. A comment of a respondent is "This book (durus al-lughah) is actually not too special, but what makes the alumni Gontor speak Arabic is a method of teaching it (Direct Method)". From this comment, it can be concluded that the KMI Gontor which is famous for its alumni that many alumni study at the $\mathrm{Al}$ Azhar University in Egypt does not depend on the medium used to teach Arabic, because it will not be as good as the direct method involving the role of teachers, classes and the atmosphere of the Islamic boarding school.

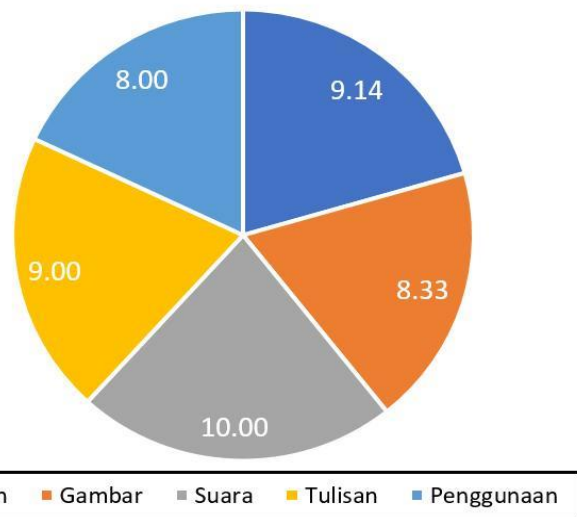

Fig. 14 The results of the questionnaire by experts of PMDG learning media.

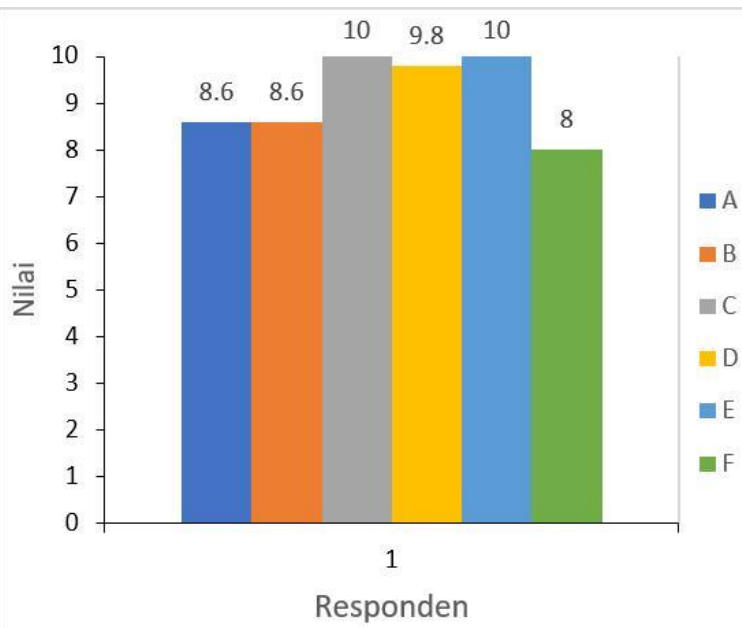

Fig. 15 The results of the questionnaires with respondents of matriculation student at Universitas Darussalam Gontor

Details of expert learning media assessment of the seven aspects of the design, the six aspects of the image, two aspects of the sound, three aspects of writing, and the seven aspects of usage are described in Fig. 14, which shows the suitability of media, materials and beginning users. 


\section{Student Matriculation Test}

This test aims to improve understanding of the Arabic language for students who do not pass the exam when registration.

Results of questionnaires involving six out of thirty students not the alumni of the Muslim boarding school about ten aspects are shown in Fig. 15. The figure shows that the media is able to facilitate beginners to learn Arabic because all students own a smartphone with the Android operating system as well as ease of use and understanding of the content material.

\section{E. Test on General Users on Play Store}

This test aims to introduce Arabic for beginners to the public.

REVIEWS

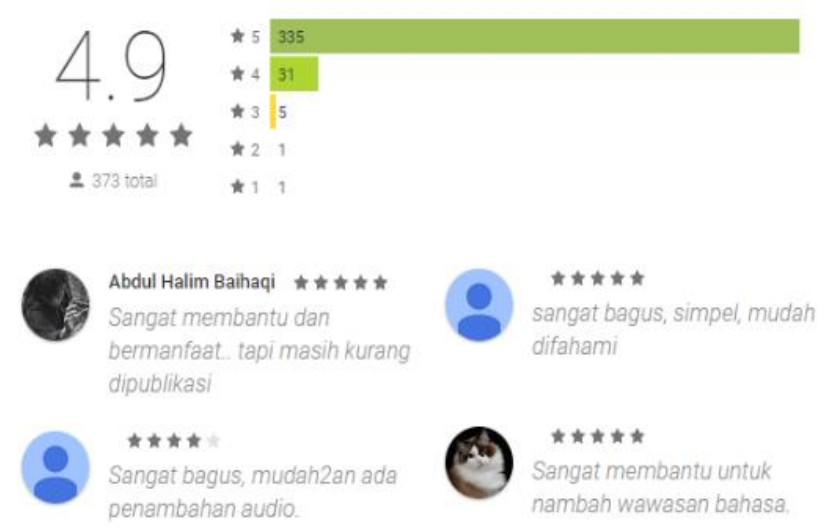

Fig. 16 The results of the questionnaire for general users on PlayStore.

Based on Fig. 16, both rating and comments show the rating 4.9 out of 5 maximum points, from 273 users, since the media was launched on February 1, 2017, until 18 November 2017. Additional information from the PlayStore is that today there are 5.399 active users of various countries, namely Indonesia, Malaysia, Egypt, India, Senegal, Ivory Coast, Qatar, Ghana, Russia, Pakistan, Thailand, Tanzania, United Arab Emirates, Argentina, Congo, South Korea, Brazil, Singapore, Nigeria, Taiwan, USA, France, Turkey, Philippines, Burundi, Spanish, Guinea, Cameroon, Sri Lanka, Sudan, Saudi Arabia, Bangladesh, New Zealand, Somalia, Brunei, and the Gambia.

\section{CONCLUSION}

The evaluation was done with six ways which its result is the suitability of the various Android devices of 4.5 inch with a minimal operating system type ICS (4.0.4); an Arabic language learning expert gave an assessment result of $95 \%$; an instructional media gave an assessment result of the mean score of $88.9 \%$; seven of eleven Arabic language lecturers gave a score of $81.4 \%$, the data sample six of the thirty students who were not alumni of the muslim boarding school gave a score of 91.6\%; and 373 general users who downloaded via Play Store since February 1, 2017, until 18 November 2017 gave 4.9 rating. The results of all these tests by the respondents to this study media show its compliance with beginning users due to ease of use. However, this media is only a means to help to learn which it cannot replace the role of teachers, classes, and schools the real atmosphere.

\section{REFERENCES}

[1] G. ICT Team, (2015) "Gontor dan Bahasa," www.gontor.ac.id [Online], https://www.gontor.ac.id/catatan/gontor-dan-bahasa, access date: 08-May-2017.

[2] U. Web Journalist, (2014) "Sejarah Universitas Darussalam Gontor," unida.gontor.ac.id, [Online], http://unida.gontor.ac.id/sejarah/, access date: 23 -Aug-2017.

[3] U. Web Journalist, (2016) "Tingkatkan Wawasan Pengetahuan, Mahasiswa Program Martikulasi Ikuti Language Visit,' unida.gontor.ac.id, [Online], http://unida.gontor.ac.id/tingkatkanwawasan-pengetahuan-mahasiswa-program-martikulasi-ikutilanguage-visit/, access date: 03-Sep-2017.

[4] D. Muriyatmoko and A. F. Abdullah, "Aplikasi Tamrin Lughoh (Pembelajaran Bahasa Arab) Pondok Modern Darussalam Gontor Berbasis Mobile," Seminar Nasional Teknologi dan Multimedia 2017, 2017, pp. 241-246.

[5] R. Basyir, M. K. Sophan, and R. Yunitarini, "Rancang Bangun Aplikasi Android Media Pembelajaran Kosa Kata Bahasa Arab Bergambar Dengan Menggunakan Model Pendekatan ADDIE," Jurnal Ilmiah Edutic, Jurnal Pendidikan dan Informatika, Vol. 3, No. 1, 2016.

[6] R. Bangun and A. Pembelajaran, "Rancang Bangun Aplikas Pembelajaran Hadis Untuk Perangkat Mobile Berbasis Android," Jurnal Informatika, Vol. 8, No. 2, pp. 907-920, 2014.

[7] W. Uriawan and H. Hidayat, "Rancang Bangun Aplikasi Pembelajaran Ilmu Sharaf Dalam Tata Bahasa Arab Berbasis Android," ISTEK Jurnal Kajian Islam, Sains dan Teknologi, Vol. 10, No. 2, pp. 107-122, 2017.

[8] M. Muhammad, D. Rahadian, and E. R. Safitri, "Penggunaan Digital Book Berbasis Android Untuk Meningkatkan Motivasi Dan Keterampilan Membaca Pada Pelajaran Bahasa Arab," Pedagogia Ilmu Pendidikan, Vol. 15, No. 2, pp. 690-701, 2017.

[9] A. R. Zaini, "Rekabentuk Aplikasi Pembangunan Kosa Kata Bahasa Arab," E-Proceeding of The Regional Conference on Civilization and Islamic Thoughts (ReCIT) 2016, 2016.

[10] M. Ritonga, A. Nazir, and S. Wahyuni, "Pembelajaran Bahasa Arab Berbasis Teknologi Informasi dan Komunikasi di Kota Padang," Pendidikan Bahasa Arab, Vol. 3, No. 1, pp. 1-12, 2016.

[11] U. Web Journalist, (2015) "UNIDA Gontor Memulai Model Pembelajaran Bahasa Arab Online," [Online], http://unida.gontor.ac.id/unida-gontor-mulai-membuat-modelpembelajaran-bahasa-arab-online/, access date: 09-Oct-2017.

[12] A. Musgamy, "Tariqah al-Qawaid Wa Al-Tarjamah," Al-Daulah, Vol 4, No. 2, pp. 391-402, 2015.

[13] T. Fitriani and T. Aljauhari Tantowie, "Metode Gramatika Terjemah untuk Meningkatkan Hasil Belajar Peserta Didik pada Mata Pelajaran Bahasa Arab," Jurnal Studi Pendidikan Islam, Vol. 13, No. 1, pp. 3140, 2016.

[14] Asnah, "Penggunaan Metode Gramatika-Terjemahan dan AudioLingual Dalam Pembelajaran Bahasa Arab," Realita: Jurnal Penelitian dan Kebudayaan Islam, Vol. 14, No. 2, pp. 89-102, 2016.

[15] D. Yani, "Metode Audio-Lingual Audio-Lingual Lingual Method in Teaching Kaiwa," Lingua Dedaktika:Jurnal Bahasa dan Pembelajaran Bahasa, Vol. 10, No. 1, pp. 9-17, 2016.

[16] N. Hanani, "Efektivitas Penggunaan Metode Mudiolingual Dalam Pembelajaran Bahasa Arab," Realita: Jurnal Penelitian dan Kebudayaan Islam, Vol. 14, No. 2, pp. 246-256, 2016.

[17] S. Sumihatul Ummah MS, "Penerapan Metode ALM (Audio Lingua Method) dalam Pembelajaran Speaking English di SMP Islam AnNidhomiyah Pamekasan," Nuansa:Jurnal Penelitian Ilmu Sosial dan Keagamaan Islam, Vol. 13, No. 1, 2016.

[18] N. Aldoobie, "ADDIE Model Analysis Phase," American International Journal of Contemporary Research, Vol. 5, No. 6, pp. 68-72, 2015. 